\title{
Objective Structured Clinical Examination for Undergraduate Surgery Finals in the College of Medicine, University of Mosul
}

\author{
Karam K. Younis, Saadallah M. Alzakko, Muddather A. Mohammed \\ Department of Surgery, College of Medicine, University of Mosul, Mosul, Iraq. \\ Correspondence: Karam K. Younis. Karam_kamal66@yahoo.com. \\ (Ann Coll Med Mosul 2018; 40 (1): 46-50). \\ Received: $3^{\text {rd }}$ May 2014; Accepted: $11^{\text {th }}$ Jun. 2018
}

\section{ABSTRACT}

Background: The objective structured clinical examination is gaining popularity in most medical schools for its validity, reliability, and objectivity. It requires a lot of physical and financial resources and commitment.

Objective: To outline steps important to be considered when conducting objective structured clinical examination as an assessment skill for final undergraduate candidates in surgery with emphasis on the student's perception, satisfaction and acceptability.

Design: A purposive sample of 151 of $6^{\text {th }}$ year undergraduate medical students attempted final objective structured clinical examination in Surgery.

Setting: Department of Surgery, College of Medicine, University of Mosul during the academic year 20112012.

Method: Purposive sample including 151 participants, who attempted objective structured clinical final examination in surgery for graduation. There were 65 males \& 86 females. The examination was performed over 8 days. A well-organized ten objective structured clinical examination stations were chosen for assessment. The time allowed for each station was 6 minutes. An objective structured clinical examination organizing committee was established. The subjects for objective structured clinical examination stations were determined, a detailed plan of the students grouping and movement was established, and a notice for all students about objective structured clinical examination details was given. At completion of examination, students were given self-administered questionnaire and feedback to test their perception and satisfaction about the examination.

Results: Data of completed self-administered questionnaire were analyzed. Regarding station information, $78.8 \%$ of students reported that the task questions in the stations are appropriate to the length of station, $82.7 \%$ replied that the stations are practical and $72.1 \%$ answered that the information in stations are clear. Reply from $86.7 \%$ was that the task was clearly stated, $82.1 \%$ responded that patient's complaint in the clinical stations is brief and given in basic language, while $74.1 \%$ replied that findings are "well understood" and clearly described. Analyzing the stations structure, $80.7 \%$ of students stated that the number of the stations was enough and $84.7 \%$ agreed that the location of stations was good.

Conclusion: Objective structured clinical examination for undergraduates' surgical finals is a practical assessment tool even if large numbers of students are involved. Data of this study showed that overall student's perception, satisfaction and acceptability of objective structured clinical examination were encouraging.

Keywords: Objective structured clinical examination, assessment, clinical, undergraduate, medical schools.

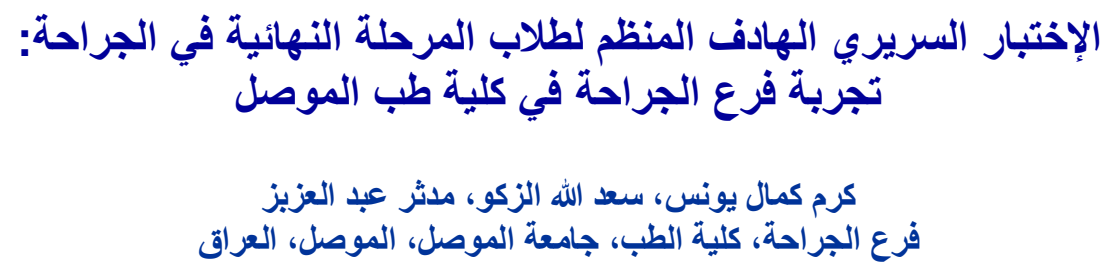


الخلفية: يحظى الإختبار السريري الهادف المنظم بشعبية منز ايدة حيث تبين أن له مصداقية وموضو عية وإعتمادية عالية. يتطلب

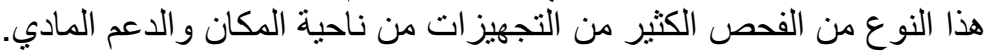

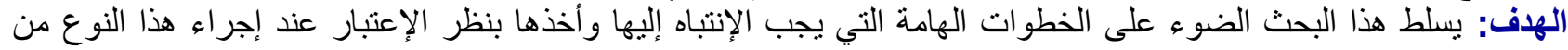

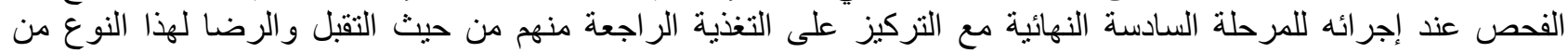

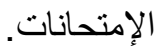
التصميم: تم دراسة عينة تتألف من الإنة 101 طالبا من المرحلة السادسة للار اسة الأولية خضعوا لإمتحان الإختبار السريري الهادف

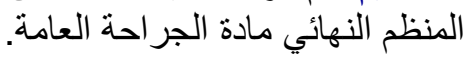

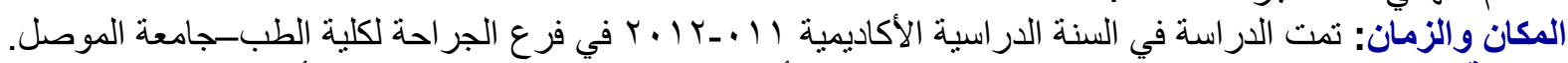

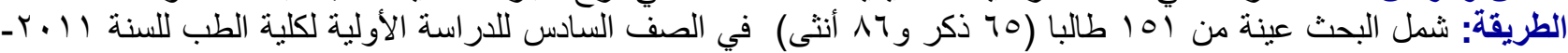

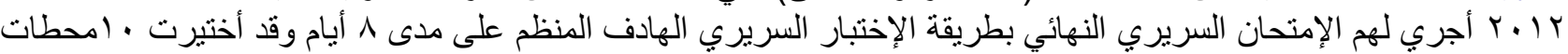

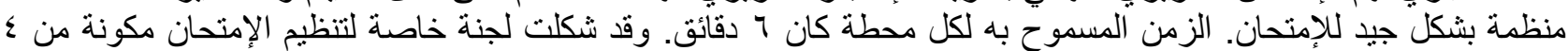

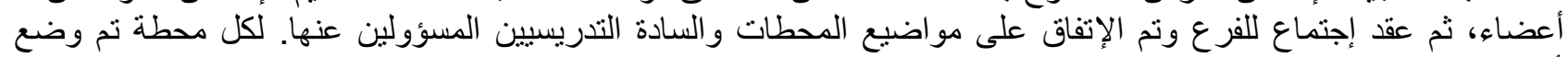

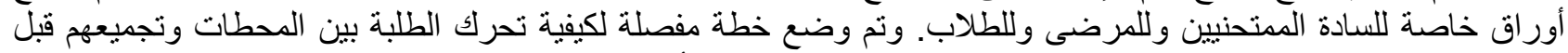

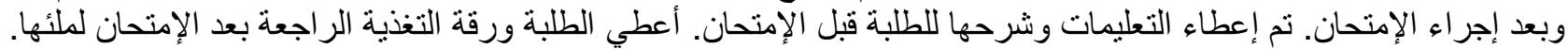

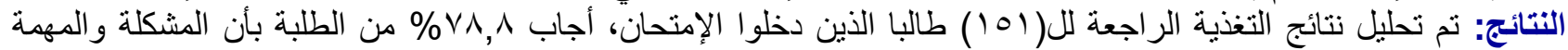

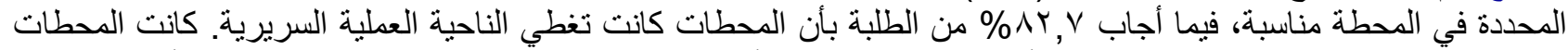

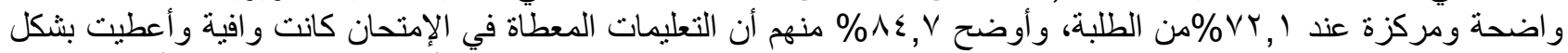

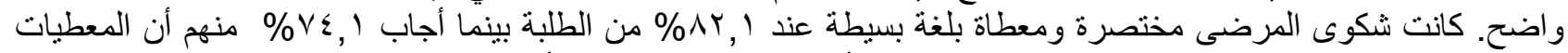

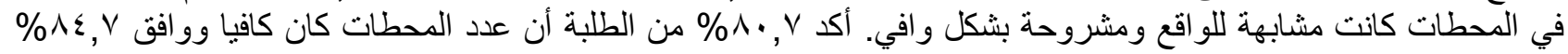
منهم على جودة نو عية ومو اقع المحطات. الإستنتاج: الإختبار السريري الذهاء الهادف المنظم الذي أجري لطلبة الصف السادس في مادة الجراحة النهائي أعطى نتائج مقبولة

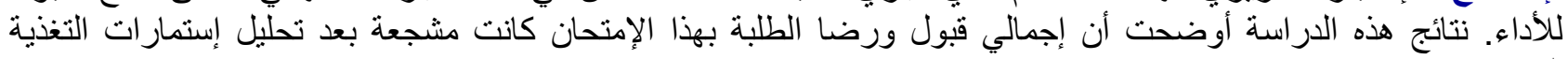

الكلمات المفتاحيه: الإختبار السريري الهادف المنظم، تقييم، سريري، طلبة كلية الطب.

\section{INTRODUCTION}

$\mathrm{O}$ bjective structured clinical examination (OSCE) had been practiced in most medical schools, many residency programs and by the Licensure Boards in Canada since the mid 1970s. ${ }^{1}$ In 1975 Harden et al $^{2}$

Introduced OSCE in an effort to improve the evaluation of medical student's clinical performance. They claimed that when used correctly, the OSCE can be highly successful as an instrument to assess skills and competence in medicine. This type of evaluation as a means of assessing clinical competency by direct observation, is being used for both under- and post- graduate students as a 'gold standard' of health professional assessment. ${ }^{3,4}$ It is increasingly replacing the traditional long-case, short-case and viva-based clinical finals where other important aspects of clinical expertise, such as physical examination skills, technical skills, problem-solving abilities, doctor-patient communication skills, decision-making abilities, and patient treatment skills are assessed objectively. ${ }^{5,6}$ All candidates are presented with the same test at each station within a specified time period, it proved to be a reliable, valid, and reproducible test. ${ }^{7}$ Many factors can influence reliability of OSCE namely the time and number of stations, the diversity of skills involved, training of the involved examiners and standardized patients, and checklists. ${ }^{8}$

The current study is an attempt to show in some detail of the experience of the Department of Surgery, College of Medicine, University of Mosul, in running OSCE for large group of undergraduate $6^{\text {th }}$ year medical students for final examination in surgery in the academic year 2011-2012.

\section{PARTICIPANTS AND METHOD}

A purposive sample included 151 sixth year undergraduate medical students during the academic year 2011-2012. The examination was performed over 8 days. Each day 19 students were examined and 12 examiners supervised the examination. There were 9 comprehensive stations (with an additional rest station) at six minutes per 
station. Each station dealt with specific medical skill, Table 1.

A detailed plan of the students grouping and movement was done Table 2.

Labels indicating station numbers, examination lines, waiting rooms and staff lounges were affixed. Students were provided with an assignment card detailing the group assignment. Student's mobile phones were switched off and taken away before the examination.

Students rotated through all stations and have to move to the next station at a signal bell. During the examination, students were observed and evaluated as they pass through the stations where they did the tasks assigned in each station.

Since the stations are generally independent, students can start at any station and complete the cycle. Thus, using 10 stations, 6 minutes each, 10 students can complete the examination within 60 minutes. As there were 19 students /day, the whole examination lasted on an average of 2 hours daily for 8 days. Time was considered as an important issue to run the examination. Three junior staffs were allocated to be responsible for timekeeping. In each active station which involves practical skill to be performed, there were 2 examiners while for each inactive station which involved data interpretation, there was 1 examiner. All examiners used checklists for the answers according to predetermined criteria. The checklists contain the standard questions / answers. The items in the checklist were used to assess the medical skill specific to the station in spot, such as: focused history, symptoms, signs, data interpretation, and management, plans.

A pre-examination introductory symposium on OSCE was established by the OSCE committee in the department addressing the guidelines for OSCE. The OSCE committee discussed through several meetings the following points:

- OSCE location and the room set up for stations.

- Examiners/staff, standardized patients (SPs),

- Catering, time and record keeping.

- Station information. Fig1.

- Instructions to candidates.

- Instructions to examiners.

- Examiner's marking guide and scoring sheet.
After completing the examination, students were given a self-administered questionnaire to test their perception and satisfaction of the examination.

\section{RESULTS}

Data of one hundred and fifty one students who attempted the OSCE and completed the questionnaire were analyzed. Replies from $82.7 \%$ of students were that the stations were practical, and $72.1 \%$ answered that the information in station provides clear focus to student. Concerning candidate's instructions, $84.7 \%$ of students perceived that basic patient information for examination was clearly given and $86.7 \%$ reported that task was clearly stated. Analyzing patients information in the clinical station, $82.1 \%$ of students responded that patient complaint was brief and given in basic language, and $74.1 \%$ replied that findings were "well understood" and clearly described. Regarding the stations structure, $80.7 \%$ of students stated that the number of stations was enough, and $84.7 \%$ agreed that the types and locations of stations were good.

One important factor in designing OSCE stations is the duration of the station and whether it is sufficient to achieve the task or not, $78.8 \%$ of the respondents stated that the duration of each station was adequate, those who felt that the time was insufficient were $21.2 \%$, Table 3.

As regard to the conduct of examination, there were no problems encountered while running the examination. It was only noted that the place of examination needs further extension. Staff and students expressed high satisfaction with this type of examination. Additional benefit was that all the students on the same day were exposed uniformly to the same staff and same assessment tools in the same environment.

Table 1. Objective structured clinical examination stations used to assess skills.

\begin{tabular}{ll}
\hline Station no. & Name of station \\
\hline Station (1) & Slides interpretation (photos) \\
Station (2) & Physical examination on real patients \\
Station (3) & Investigation (data interpretation \\
Station (4) & Focenarios, radiology films) \\
Station (5) & Instrument \\
Station (6) & Examination skills on a dummy \\
Station (7) & Orthopedics \\
Station (8) & Emergency and CPR \\
Station (9) & Urology \\
Station (10) & Rest \\
\hline
\end{tabular}


Table 2. Students grouping and movements

\begin{tabular}{lcl}
\hline Group/time. & No & Movements line \\
\hline 8.30-9.00 Am & 18 & $\begin{array}{l}\text { All students directed to } \\
\text { secretariat room for ID } \\
\text { check and assignment card. } \\
\text { \& label distribution }\end{array}$ \\
9.00-9.20 Am & 18 & $\begin{array}{l}\text { All students attempted } \\
\text { surgical slide station exam } \\
\text { in one hall } \\
\text { Students will come out from } \\
\text { slide hall and will be } \\
\text { allocated to the stations in } \\
\text { unidirectional flow with } \\
\text { continued supervision of the } \\
\text { remaining } 9 \text { students in the } \\
\text { surgical slide station hall }\end{array}$ \\
\hline 10.30-11.30 Am & 9 & $\begin{array}{l}\text { Students will come out from } \\
\text { surgical slide hall and will } \\
\text { be allocated to the stations } \\
\text { in unidirectional flow }\end{array}$ \\
\hline
\end{tabular}

Table 3. Summary of questionnaire results

\begin{tabular}{|c|c|c|}
\hline TASK & $\begin{array}{c}\text { GOOD } \\
\text { (no.) }\end{array}$ & $\begin{array}{l}\text { NEEDS FURTHER } \\
\text { EVALUATION } \\
\text { (no.) }\end{array}$ \\
\hline $\begin{array}{l}\text { Problem or question is- } \\
\text { appropriate to time of } \\
\text { station }\end{array}$ & 131 & 20 \\
\hline $\begin{array}{c}\text { The required skill or } \\
\text { question is real to life OR } \\
\text { PRACTICAL }\end{array}$ & 125 & 26 \\
\hline $\begin{array}{l}\text { Provide(s) clear focus to } \\
\text { student }\end{array}$ & 109 & 32 \\
\hline $\begin{array}{l}\text { Basic patients information } \\
\text { are clearly given }\end{array}$ & 117 & 34 \\
\hline Task is clearly stated & 131 & 20 \\
\hline $\begin{array}{l}\text { Patient s complaint is } \\
\text { brief and in basic } \\
\text { language }\end{array}$ & 124 & 27 \\
\hline $\begin{array}{c}\text { Findings are "well } \\
\text { understood" \& clearly } \\
\text { described }\end{array}$ & 128 & 23 \\
\hline $\begin{array}{l}\text { Number of stations } \\
\text { /examination }\end{array}$ & 122 & 29 \\
\hline $\begin{array}{l}\text { Types of \& location of } \\
\text { stations/examination }\end{array}$ & 132 & 19 \\
\hline Time /duration of stations & 119 & 32 \\
\hline
\end{tabular}

\section{DISCUSSION}

Clinical skills examinations, such as OSCEs, are daunting but are essential component of medical undergraduate education. ${ }^{9}$ However controversy still exists. Bora et $a l{ }^{5}$ stated that although OSCE style finals are fairer than the traditional style of clinical finals, they are not a perfect assessment of competence. Until an OSCE begins, candidate stress is high, students had to pull together vast amount of information from many resources. ${ }^{4}$ This tedious and time consuming process can be avoided, if information about stations and conduct of OSCE structure were successfully given, a fact that was already attempted by the Department of Surgery through introductory symposia. The principles of running OSCE examinations do not differ regardless the number of students. Yet, the logistics of running such an examination for 150 or more students are extensive..$^{9,10}$

In his study, Davis ${ }^{11}$ stated that a high degree of discipline and enthusiasm are required, and a big number of examiners and support staff are essential.

In the current study, despite many obstacles regarding the place of examination and the shortage of examination staff, OSCE examination was successfully established by our department. Capriccio, Englander ${ }^{12}$ and Abdulla ${ }^{13}$ reported that a very important factor in the success of the examination is meticulous and detailed written documentation of every aspect. ${ }^{12,13}$ This was achieved by frequent meetings of the examination committee to ensure that all parts of the stations coordinate with all aspects of skills and that stations checklists contained the standard questions/ answers in order to avoid bias in putting marks.

Concerning the rules for the examination which were established by the Department of Surgery, it appears to be consistent with the rules of Petrusa $^{14}$ and Talal ${ }^{15}$ who pointed that for reasons of confidentiality, students must be in the examination area before the actual examination. They also need to be kept in spacious rooms under supervision to avoid contact between the different groups via mobile telephones. Because of the parallel lines of stations, time keeping is very important. A 6-minute period per station is usually sufficient to organize the movement of the students.

In regard to the analysis of self-administered questionnaire, it appeared that the majority of students expressed their acceptability and satisfaction with the structure of the stations as 
more than one third of students felt that OSCE stations information and time were adequate. These findings were different from the study of Abdulla $^{13}$ in Basrah who reported that student who were satisfied with OSCE formed only $20.4 \%$ whereas $48 \%$ of students stated that the duration of station was adequate. Regarding the use of standardized patients, $58 \%$ of Basrah students accepted the use of such patients while $82.1 \%$ of our students responded that the information given in the clinical station was clear.

\section{CONCLUSION}

Data of this study showed that overall student's perception, satisfaction and acceptability of OSCE were encouraging. Proper preparation by OSCE committee in the Department, the cooperation of the Department members and the availability of the requirements had a great deal to do with this success. A timely feedback on the performance of the candidates after applying the standards of OSCE was a fact that we learned through this experience.

\section{ACKNOWLEDGMENTS}

We would like to express our deep and great respect and thanks to the former Dean of the College of Medicine Prof. Muzahim Al-Kahyyat for his support and guidance.

We also express our great thanks to all teaching staff and members of the Department of Surgery, College of Medicine, University of Mosul for their active participation in this experience, and we appreciate all comments and advices which added a lot and aided in the success of this work.

\section{REFERENCES}

1. llic D. Assessing competency in evidence based practice: strengths and limitations of current tools in practice. BMC Med Educ [online]. 2009 [cited 2009 Dec 16]; 9:53. Available from http://www.biomedcentral. com/1472- 6920/9/53.
2. Harden RM, Stevenson M, Downie WW, Wilson GM. Assessment of clinical competence using objective structured examination. Br Med J 1975; 1(5955): 447451.

3. Hatem HA, Objective Structured Clinical Skill Examination (OSCE) Medical Journal of Babylon2010: 7 (1-2): 29-30.

4. Abdulla MA, OSCE: things to be said. Bas J Surg 2010; 16: 30.

5. Bora Sh, Heah Th, Thakor Sh: OSCE for Medical and Surgical finals. New York: Oxford University Press; 2005.

6. Al-Youzbaki D B. Developing a communication skills training program for the undergraduate medical students. Mosul, Iraq: Mosul, Medical College, Mosul University; 2005.

7. Van der Vleuten $\mathrm{C}$. The assessment of professional competence: developments, research and practical implications, Adv in Health Sci Edu 1996; 1: 41-67.

8. Wilkinson TJ, Newble DI, Wilson PD, Carter JM, Helms RM. Development of a three centre simultaneous objective structured clinical examination. Med Educ 2000; 34(10): 798-807.

9. Burton L N, Birdi K. Clinical Skills for OSCEs $.2^{\text {nd }}$ ed. UK: Informa healthcare; 2006.

10. Rekany A J, Al-Dabbagh S A. Validity and reliability of OSCE in evaluating practical performance skills of interns in emergency Medicine. Duhok Med J 2010; 4(2):21-29.

11. Davis MH. OSCE: the Dundee experience. Med Teach 2003; 25(3): 255-261.

12. Carraccio $C$, Englander $R$. The objective structured clinical examination: a step in the direction of competency-based evaluation. Arch Pediatr Adolesc Med 2000; 154(7): 736-741.

13. Abdulla M. A students perception of objective structured clinical examination (OSCE) in surgery at Basrah College of Medicine Bas J Surg, 2012; 18: 345

14. Petrusa ER. Taking standardized patient-based examinations to the next level. Teaching and learning in Medicine 2004; 16:98-110.

15. Bakhsh TM, AL Kashgari RH, Sibiany AM, Al-Mashat FM, Meccawy AA, Al Thubaity FA and AlJohary A A: Running OSCE for a Large Group of Students: Experience of the Surgical Department, King Abduaziz University, Faculty of Medicine. JKAU Med Sci 2005; 12:43-52. 